\title{
Environmental Analysis of The Impacts of Batik Waste Water Polution on The Quality of Dug Well Water in The Batik Industrial Center of Jenggot Pekalongan City
}

\author{
Slamet Budiyanto ${ }^{1)}$, Anies ${ }^{2)}$, Hartuti Purnaweni ${ }^{3)}$, Henna Rya Sunoko ${ }^{2)}$ \\ ${ }^{1}$ Doctoral Program of Environmental Science, School of Postgraduate Studies, Diponegoro University, Semarang-Indonesia \\ ${ }^{2)}$ Faculty of Medical Diponegoro University \\ ${ }^{3)}$ Faculty of Social Science and Political Science Diponegoro University
}

\begin{abstract}
The city of Pekalongan known as "Kota Batik" is one of Batik Industrial Centers in Indonesia with 917 batik industry. There are 203 batik industries located in Jenggot Village, which is the biggest batik industrial center in Pekalongan City. The process of making batik requires a dye derived from synthetic dyes containing heavy metals. Most of the waste is directly discharged into the environment without going through the processing first. This is due to the lack of optimal management of existing WWTP as well as lack of public awareness of environmental conservation. This condition has a negative impact on the surrounding community, especially in terms of environmental health. The result of measurement of 5 (five) batik industrial waste outlets and 5 point of batik waste water in residential sewer shows almost equal number for 3 (three) parameters of heavy metals $\mathrm{Cd}, \mathrm{Cr}$ and $\mathrm{Pb}$ with average number: $\mathrm{Cd} 0.07 \mathrm{Mg} / \mathrm{L}, \mathrm{Cr} 0.76 \mathrm{mg} / \mathrm{L}$ and $\mathrm{Pb} 0.78 \mathrm{mg} / \mathrm{L}$. These three parameters exceed the maximum level of quality standard established by Government Regulation No.82 of 2001 on Water Quality Management and Water Pollution Control. The average result of the water quality measurement of the well digging population to the heavy metal content are: $\mathrm{Cd} 0,001 \mathrm{mg} / \mathrm{L}, \mathrm{Cr} 0,002 \mathrm{mg} / \mathrm{L}$ and $\mathrm{Pb} 0.04 \mathrm{mg} / \mathrm{L}$. Of the three parameters of heavy metals, heavy metals of $\mathrm{Pb}$ are on average higher than the maximum level of quality standards established by Decree of the Minister of Health Number. 492 / Menkes / Per / IV / 2010 regarding Water Quality Requirements. Potential occurrence of dug well water contamination due to infiltration of batik waste water is big enough. Survey results of $15 \mathrm{dug}$ wells show that the construction of dug wells is not sufficient. There is a dug well with a damaged outer wall of $16.1 \%$, damaged inner wall of $17.9 \%$ and a damaged well floor of $19.7 \%$. Improper well construction impacts on the infiltration of batik waste water into the well. Survey results of physical well water quality showed $3.6 \%$ snoring, $16.1 \%$ smelly, $9.8 \%$ color and $10.7 \%$ taste. Pollution to dug well water can affect public health because it is used for daily use to drink, cook, bathe and wash because $>65 \%$ do not have other sources of clean water. The recommendation of this research is the need for waste water treatment batik starting from source through WWTP both on the household and communal scale with the role of local government as a facilitator. Society and batik industry players need to be involved in managing environmentally friendly batik industrial center.
\end{abstract}

\section{Introduction}

Water is one of the most important natural resources for the fulfillment of the needs of human life and other living things. One of clean water sources used by residents is ground water from shallow wells. Therefore, the quality of shallow well water is needed by people who use it for their daily needs such as for bathing, washing, drinking and cooking.

Shallow well water quality is strongly influenced by the quality of the surrounding environment. The existence of environmental pollution around the well has an impact on water quality. The occurrence of pollution on the environment caused by several things such as industrial activities in the area. Industrial activities will not affect the environment if they are managed properly. if the industrial activities are not managed properly, it will have an adverse impact on the environment.

One kind of industries that has the potential to pollute an environment is batik industry. The process of the making of batik in batik industry includes stages of painting, wax covering, coloring, wax cleansing, washing, and drying uses raw material gray cloth, synthetic dyes, wax, energy and water.

Pollution caused by batik industry is dyestuff waste. As it is known that many coloring in batik dye synthetic dyes because the price is relatively cheaper when it is compared with natural dyes. The use of synthetic dyes in

\footnotetext{
*Corresponding author: ibudks@yahoo.com
} 
the batik industry produces dyestuff waste that degrade water quality. Synthetic dyestuff waste which discharged in waters is non-biodegradable, and cannot be decomposed by microorganisms [1].

The coloring for batik clothes that it is now done by crafts men uses synthetic dye. Synthetic dyes are widely used by artisans as base dyes and Diazo direct. Synthetic dyes contain heavy metals such as $\mathrm{Cd}, \mathrm{Cr}, \mathrm{Pb}, \mathrm{Co}, \mathrm{Cu}$, $\mathrm{Hg}, \mathrm{Ni}, \mathrm{Mg}, \mathrm{Fe}$ and $\mathrm{Mn}$. Heavy metals are used to increase the bonding strength between dyes and fabrics [2].

Suprihatin [3] states that one of the most popular examples of dyestuffs used in the textile industry is the black, red and golden yellow remazol. In staining, this compound is only used about $5 \%$ while the rest of $95 \%$ will be disposed of as waste. This means that the dyestuff which effectively binds the fabric is only $5 \%$ while the rest are wasted.

The city of Pekalongan known as "Kota Batik" is one of the cities located in the coastal region which has batik industries as the most dominant activities of its population. According to the document of Environment Agency of Pekalongan City, in the year of 2014, Pekalongan City has 917 batik industries spread in 4 (four) subdistricts namely 247 batik industries in West Pekalongan District, 124 batik industries in East Pekalongan District, 104 batik industries in North Pekalongan District, and 442 batik industries or about $48.2 \%$ batik industries are located in South Pekalongan District.

Of the 442 batik industries located in South Pekalongan District, about $46.3 \%$ of them or about 203 batik industries are located in Jenggot Village, which is the biggest batik industrial center in Pekalongan City, occupying $35.382 \mathrm{~m} 2$ area, and having production per month 25,095 codies or about 501,900 batik products per month, consisting of batik cap and batik combination, using clean water $15,505 \mathrm{~m} 3$ per month and disposing waste water as much as $12,404 \mathrm{~m} 3$ per month mostly directly to the environment without prior processing and with potency of a negative impact on the surrounding community, especially for the health of the environment health.

The activities of Batik industries in Pekalongan City can be the cause of environmental damage such as the occurrence of water pollution and soil contamination due to waste water disposal by batik industry which reached $73,878 \mathrm{~m} 3$ per month to the environment without going through a prior waste treatment. If the industry disposes liquid waste, then the waste course will pass through the waters around the settlement. Thus the quality of the neighborhood where the population lives is decreasing. The waste can increase organic content such as COD, BOD, TSS and $\mathrm{pH}$. If this exceeds the permissible threshold, then the most easily known symptom is the death of aquatic organisms [4].

Some batik dyes containing $\mathrm{Cd}, \mathrm{Pb}, \mathrm{Cu}$, and $\mathrm{Cr}$ such as $\mathrm{Na}_{2} \mathrm{Cr}_{2} \mathrm{O}_{7}$ or $\mathrm{Na}_{2} \mathrm{Cr}_{3} \mathrm{O}_{7}$ are very dangerous and other compounds included in the category of hazardous and toxic substances (B3) are highly reactive $\mathrm{H}_{2} \mathrm{O}_{2}$ and toxic $\mathrm{HClO}$. Water pollution by heavy metals has long been a serious problem that needs to be addressed, given the ever-increasing volume of waste, the toxic properties of heavy metals, and the introduction of heavy metals into water bodies can affect water quality [5] Dyestuffs in batik waste are disposed of without prior water treatment into waters, which indirectly can endanger the health. [6]. The purpose of this study is to determine the quality of batik waste water discharged directly to the residential channel and its impact on the quality of well water dug in the center of batik industry Jenggot Pekalongan City.

\section{Methodology}

\subsection{Place and time of research}

This research was conducted at Industrial Centre Batik Jenggot Pekalongan City area by assigning places of waste water source where the batik industry exists. and sewage waste is in the sewer in residential area and at well dug of its population. The measurement was conducted in August 2016, while the interviews of respondents were conducted in January 2017.

\subsection{Research design}

The design of this research is analytical descriptive by measuring the quality of industrial waste water batik as a source of pollution, especially on the parameters of heavy metals $\mathrm{Cd}, \mathrm{Cr}$ and $\mathrm{Pb}$, then measuring the quality of puddles of waste water in the settlement sewer. The result of the measurement is compared by using the quality standard according to Government Regulation No.82 of 2001 [7]. If the value is greater than the value of the quality standard, it means it has been polluted. Next, measuring the quality of dug well water of residents which is located around the puddle waste on the parameters of heavy metals $\mathrm{Cd}, \mathrm{Cr}$ and $\mathrm{Pb}$. The result is compared by using the quality standard according to Kepmenkes RI Number. 492 / Menkes / Per / IV / 2010 [8] If the value is greater than the value of the quality standard, it means the well water has been polluted.

\subsection{Population and sample}

The population of this research is the environment of Batik Industry Centre Jenggot Pekalongan City. The sample taken as a purposive sampling is at the source of waste water in the batik industry centre of Jenggot, the waste water puddle in the residential sewers, in which there are 5 sample points for each, and some well water in the population around the puddle of sewage in the residential, 3 sample points for each, so that the number of samples of dug wells are 15 samples.

\subsection{Variables of research}

The variables of this study are the quality of dug well water with heavy metal parameters $\mathrm{Cd}, \mathrm{Cr}$ and $\mathrm{Pb}$ as dependent variables, and its independent variables are the values of heavy metal parameters $\mathrm{Cd}, \mathrm{Cr}$ and $\mathrm{Pb}$ in 
batik industry waste water and waste water puddle in the sewer population.

\subsection{Data processing}

Waste water samples at industrial source of batik as well as in puddles in residential sewer were taken then the value of the heavy metal consisted of $\mathrm{Cd}, \mathrm{Cr}$ and $\mathrm{Pb}$ measured at Water Laboratory and then analyzed. The value of heavy metals parameters is then compared with the river water quality standard in accordance with Government Regulation no. 82 Year 2001. The condition is polluted if the value of $\mathrm{Cd}, \mathrm{Cr}$ and $\mathrm{Pb}$ result of measurement in Laboratory is greater than the value on the quality standard. Likewise, for the samples of dug well water around the puddles of waste water are measured for their values of heavy metals consisted of $\mathrm{Cd}, \mathrm{Cr}$ and $\mathrm{Pb}$ at the same laboratory. The result is compared with the quality standard according to Kepmenkes RI Number. 492 / Menkes / Per / IV / 2010 regarding Water Quality Requirements. If the value is greater than the value of the quality standard, it means the well water has been polluted is not qualified for drinking water.

\section{Result and discussion}

\subsection{Description of area}

The study was conducted at Industrial Batik Centre of Pekalongan City, Central Java Province. Batik Jenggot Industrial Centre is chosen because it is the largest Batik Industrial Centre in Pekalongan City and the batik industry activity has been running long enough as a hereditary activity. The spatial scope of the research location of Batik Industry Centre of Pekalongan City covers its area and the area around it.

a. Area of $\pm 35,382 \mathrm{~m} 2$, as a place to agglomerate various types of batik, stamp and printing industries that are heterogeneous and are thought to be the source of impact for the environment within the batik industry centre of Jenggot as well as in the surrounding environment. In batik industrial centre there are 203 batik industries with total production per month of 501,900 pieces of batik products and most of the waste water disposal without going through waste management of $12.404 \mathrm{~m} 3$.

b. The area around the batik industry centre of Jenggot is identified as directly affected by the activities in the industrial center. Batik Industrial Centre in Pekalongan City is a coastal ecosystem consisting of land sub-systems (industry, settlements, offices and commerce). The landscape is located in South Pekalongan District shown in Figure 1. As follows:
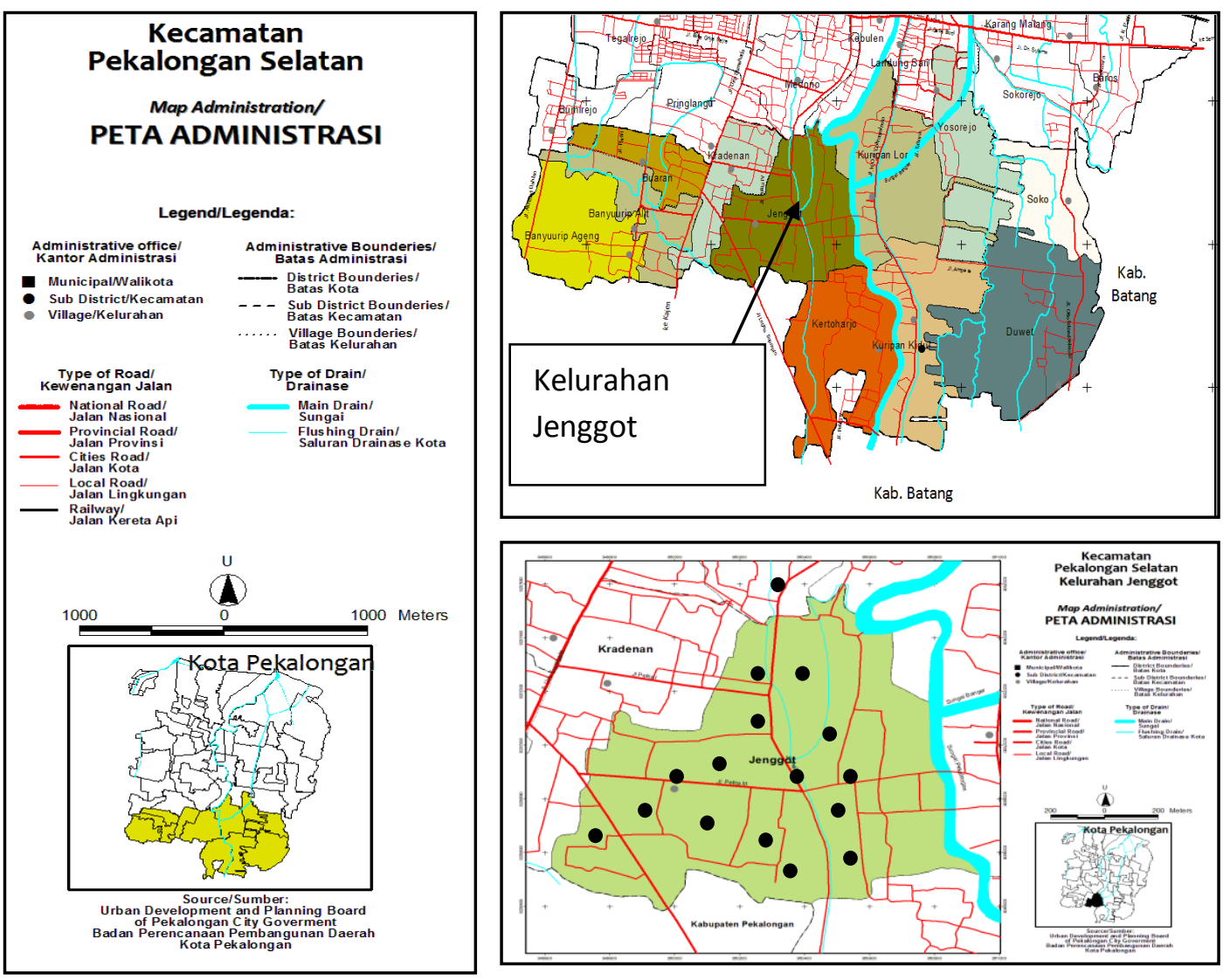

Figure 1. Maps of Research Sites Ex. Jenggot (Source: Pekalonga's Regional Planning Agency, 2015) 


\subsection{Waste water quality from the sources}

Table 1. Quality of Waste water at Batik Industrial Outlet Baku heavy metal Parameter Quality Content Waste water

\begin{tabular}{|c|c|c|c|c|c|c|c|}
\hline \multicolumn{3}{|c|}{ Quality } & \multicolumn{5}{|c|}{ Waste water Source } \\
\hline $\begin{array}{c}\text { Parameters of } \\
\text { heavy metals }\end{array}$ & $\begin{array}{c}\text { Standard } \\
\text { parameters } \\
\text { Max }\end{array}$ & Method & $\begin{array}{c}\text { Outlet } \\
1\end{array}$ & $\begin{array}{c}\text { Outlet } \\
2\end{array}$ & $\begin{array}{c}\text { Outlet } \\
3\end{array}$ & $\begin{array}{c}\text { Outlet } \\
4\end{array}$ & $\begin{array}{c}\text { Outlet } \\
5\end{array}$ \\
\hline Cadmiun $(\mathrm{Cd})$ & $0,003 \mathrm{mg} / \mathrm{L}$ & SNI 6989162009 & 0,07 & 0,07 & 0,07 & 0,07 & 0,07 \\
\hline Total Crom $(\mathrm{Cr})$ & $0,05 \mathrm{mg} / \mathrm{L}$ & SNI 6989172009 & 0,76 & 0,76 & 0,76 & 0,76 & 0,76 \\
\hline Lead $(\mathrm{Pb})$ & $0,01 \mathrm{mg} / \mathrm{L}$ & SNI 6989182009 & 0,79 & 0,79 & 0,77 & 0,79 & 0,78 \\
\hline
\end{tabular}

Source: Field data (2016).

The result of the measurement of heavy metal content in waste water at the source of 5 points of batik industrial outlet is as above. Based on table 1 above, the scoring value is almost the same in each outlet. This indicates that the materials, composition and dosage used in the batik process are almost identical. When compared with the Standards of Quality, then all the numbers for the parameters of heavy metals $\mathrm{Cd}, \mathrm{Cr}$ and $\mathrm{Pb}$ has exceeded the maximum levels set. The highest figure contained in the parameter measurements Heavy metal
$\mathrm{Pb}$ which are much higher when compared with the maximum levels set as a quality standard.

\subsection{The quality of waste water of sewer puddle of population}

The result of the measurement of heavy metal content in the waste water puddle in residential sewer that at 5 points of puddles is as follows:

Table 2 Waste water Quality in the sewer puddle of Population

\begin{tabular}{cccccccc}
\hline $\begin{array}{c}\text { Parameters of heavy } \\
\text { metals }\end{array}$ & $\begin{array}{c}\text { Quality standards } \\
\text { Max }\end{array}$ & Method & Sewer 1 & Sewer 2 & Sewer 3 & Sewer 4 & Sewer 5 \\
& & & & & & & \\
\hline Cadmiun $(\mathrm{Cd})$ & $0,003 \mathrm{mg} / \mathrm{L}$ & SNI 6989162009 & 0,07 & 0,07 & 0,07 & 0,07 & 0,07 \\
Total Chrom $(\mathrm{Cr})$ & $0,05 \mathrm{mg} / \mathrm{L}$ & SNI 6989172009 & 0,76 & 0,78 & 0,76 & 0,76 & 0,76 \\
Lead $(\mathrm{Pb})$ & $0,01 \mathrm{mg} / \mathrm{L}$ & SNI 6989182009 & 0,76 & 0,79 & 0,79 & 0,77 & 0,75 \\
\hline
\end{tabular}

Source: Field data (2016).

Table 3 Quality of Well Water Dug around Wading Batik Batik Waste on Residential Sewage

\begin{tabular}{clccc}
\hline & Location & \multicolumn{3}{c}{ Parameters of heavy metals } \\
\cline { 3 - 5 } & & Cadmiun (Cd) & Total Chrom (Cr) & Lead (Pb) \\
\hline \multirow{2}{*}{ Puddle 1 } & Dug Wells $<10$ meters & 0,001 & 0,02 & 0,04 \\
& Dug Wells 10-15 meters & 0,001 & 0,02 & 0,04 \\
& Dug Wells $>15$ meters & 0,001 & 0,02 & 0,04 \\
Puddle 2 & Dug Wells $<10$ meters & 0,001 & 0,04 \\
& Dug Wells 10-15 meters & 0,001 & 0,02 & 0,04 \\
Puddle 3 & Dug Wells $>15$ meters & 0,002 & 0,02 & 0,04 \\
& Dug Wells $<10$ meters & 0,001 & 0,02 & 0,04 \\
& Dug Wells 10-15 meters & 0,002 & 0,02 & 0,04 \\
& Dug Wells $>15$ meters & 0,001 & 0,01 & 0,04 \\
Puddle 4 & Dug Wells $<10$ meters & 0,001 & 0,003 & 0,04 \\
& Dug Wells 10-15 meters & 0,001 & 0,003 & 0,04 \\
Quality Standards Max & Dug Wells $>15$ meters & 0,001 & 0,003 & 0,04 \\
& Dug Wells $<10$ meters & 0,001 & 0,003 & 0,04 \\
& Dug Wells 10-15 meters & 0,001 & 0,003 & $0,01 \mathrm{mg} / \mathrm{L}$
\end{tabular}


Based on table 2 above, the scoring value is almost the same in every sewer. Comparing to the numbers from the measurement result at outlet, the scoring value shows an almost the same result. This indicates, the waste water flowing from outlet to the settlement area is not changing. If it is compared with the standard quality, all numbers for heavy metal parameters $\mathrm{Cd}, \mathrm{Cr}$ and $\mathrm{Pb}$ have exceeded the specified maximum level. The highest measurement figures are in the parameters of $\mathrm{Pb}$ heavy metals whose numbers are much higher when compared to the maximum levels set as the quality standard.

\subsection{Dug well water quality}

The results of the measurement of heavy metal content in the dug well water of residents, 3 points for each puddle with a distance of $<10$ meters, $10-15$ meters and $>$ 15 meters are tabulated in Table 3.

Based on Table 3, the number of measurements of heavy metals in dug wells for parameters $\mathrm{Cd}$ and $\mathrm{Cr}$ is below the maximum level on the quality standard, while the parameter of heavy metal $\mathrm{Pb}$ measurement figures are above the maximum level on the quality standard. This indicates that there has been contaminations on dug wells which exist in the population settlement around the pool of batik waste water. Azumi [9] analyzed the impact of industrial waste water on and Barthi [10] surface water and found several types of heavy metals present in such surface waters as zinc, copper, chromium, lead, iron, cadmium, and mangan. The well water is a shallow groundwater which starts from infiltration of rain water into the soil. Dyestuffs in aquatic environments can actually decompose naturally by the presence of sun light, but this reaction is relatively slow, due to the intensity of UV light that reaches the surface of earth is relatively low so that the accumulation of dye to the bottom of the water or soil is faster than the photodegradation [4]. If the industry disposes liquid waste, then the waste stream will pass through the waters around the settlement. Thus the quality of the neighborhood where the population lives down.

\subsection{Potential of impact pollution to environment and population health}

\subsubsection{Construction of Dug Well}

Dug wells which exist in Jenggot Village have potentials to be contaminated by batik waste water. From the survey of 112 dug wells in Batik Jenggot Industrial Center, the construction aspect is described in Table 4 below:

Table 4 Construction Condition Dug Well Population

\begin{tabular}{ccccccccc}
\hline & \multicolumn{3}{c}{ Construction Condition } & \multicolumn{2}{c}{ Total } \\
\cline { 2 - 9 } Indicator Observed & Good & $\%$ & $\begin{array}{c}\text { Medium } \\
\text { Damage }\end{array}$ & \% & $\begin{array}{c}\text { Heavy } \\
\text { Damage }\end{array}$ & \% & Amount & $\%$ \\
\hline Outer Wall & 94 & 83,9 & 18 & 16,1 & 0 & 0 & 112 & 100,00 \\
Inner wall & 92 & 82,1 & 14 & 12,5 & 6 & 5,4 & 112 & 100,00 \\
Wells Floor & 90 & 80,4 & 17 & 15,2 & 5 & 4,5 & 112 & 100,00 \\
\hline
\end{tabular}

Source: Field Data (2017)

Based on the data in Table 4, there are still more pollution potentials to dug wells because there are still $16.1 \%$ of damage of outer wall, $17.9 \%$ of damage of inner wall and $19.7 \%$ well with damage of well floor. Improper well construction will potentially infiltrate batik waste water into the well.

\subsubsection{Physical Quality of Dug Well Water}

The pollution to dug well water can be known earlier based on its physical quality. From the survey results of 112 dug wells in the Batik Jenggot Industrial Center, and the aspect of physical quality of dug well water is described in the table 5 .

Table 5 Physical Quality of Well Water Dug Population

\begin{tabular}{ccccccc}
\hline Water Physical & \multicolumn{3}{c}{ Conditions of Well Water Dug } & \multicolumn{2}{c}{ Total } \\
\cline { 2 - 6 } $\begin{array}{c}\text { Indicator } \\
\text { Observed }\end{array}$ & Yes & \% & No & \% & Amount & $\%$ \\
\hline Clear & 108 & 96,4 & 4 & 3,6 & 112 & 100,00 \\
No Smell & 94 & 83,9 & 18 & 16,1 & 112 & 100,00 \\
Colorless & 101 & 90,2 & 11 & 9,8 & 112 & 100,00 \\
No Taste & 100 & 89,3 & 12 & 10,7 & 112 & 100,00 \\
\hline
\end{tabular}

Source: Field Data (2017)

Based on the data in table 5, there are water wells that physically are not qualified. There are 3.6\% turbid well water, $16.1 \%$ smelly water, $9.8 \%$ colored water and $10.7 \%$ taste. 


\subsubsection{Utilization of Dug Well Water}

The existence of dug wells is one of the important things in Jenggot Urban Village.

From the approximately 1,200 heads of households, there are approximately $75 \%$ of people still relying on dug wells as a source of clean water. From the survey of 112 digging wells in Batik Jenggot Industrial Center, the utilization of dug well water is described in Table 6 .

Based on the data in Table 3.6, dug well water is used daily drinking, cooking, bathing and washing. If the water used is polluted by heavy metals due to batik waste, it will cause the entry of heavy metals into the human body, especially through ingestion process (digestion). As many as $65.2 \%$ of families say they do not have other sources of clean water, the potential for bioaccumulation of heavy metals in the body due to daily use can occur. Heavy metals of $\mathrm{Pb}$ or lead is one element of heavy metals that are toxic to living things including humans. The influence of $\mathrm{Pb}$ [12] on human health can damage the nervous system, kidney and reproductive system. Hasan [13] states that the implementation of sustainable waste water management including proper treatment of waste water and industrial waste is essential to protect ecosystems and also to prevent the further damage of the surface water quality in this area.

Table 6 Utilization of Well Water Dug Population

\begin{tabular}{ccccccc}
\hline Utilization & \multicolumn{3}{c}{ Condition } & \multicolumn{2}{c}{ Total } \\
& Yes & $\mathbf{\%}$ & $\mathbf{N o}$ & $\mathbf{\%}$ & Amount & A \\
\hline Drinking water & 85 & 75,9 & 27 & 24,1 & 112 & 100,00 \\
Cook & 93 & 83,0 & 19 & 17,0 & 112 & 100,00 \\
Bath & 111 & 99,1 & 1 & 0,9 & 112 & 100,00 \\
Wash & 111 & 99,1 & 1 & 0,9 & 112 & 100,00 \\
Don't have another Source of Clean Water & 73 & 65,2 & 39 & 34,8 & 112 & 100,00 \\
\hline
\end{tabular}

Source: Field Data (2017)

\section{Conclusion and Recommendation}

\subsection{Conclusion}

Batik waste water from batik industry outlets contains heavy metals $\mathrm{Cd} \mathrm{Cr}$ and $\mathrm{Pb}$ which exceed the required standard of environmental quality. This happens also on batik waste water pools in residential sewers and on dug well water around the gutter. On dug well water around the gutter only $\mathrm{Pb}$ which levels exceeds the required environmental quality standard. There were $16.1 \%$ of damaged wells, $17.9 \%$ of damaged internal walls and $19.7 \%$ of wells with damaged well floors. The potential for infiltration of batik waste water into the well. The physical condition of dug wells has the potential to contaminate batik waste water, there are $3.6 \%$ turbid well water, $16.1 \%$ smelly water, $9.8 \%$ colored water and $10.7 \%$ taste. Pollution to dug well water can have an impact on public health because it is used for daily use to drink, cook, bathe and wash because $>65 \%$ has no other sources of clean water.

\subsection{Recommendation}

The recommendation of this research is the need for waste water treatment batik starting from source through WWTP both on the household and communal scale with the role of local government as a facilitator. Society and batik industry players need to be involved in managing environmentally friendly batik industrial center.

\section{References:}

1. S. Widyaningsih, D. W Dwiasi., and D. Hidayati., 9(2), 166-174. (2014).
2. Yuniarto, D. R dan Iqbal Achmad, Jurnal Teknologi Pengelolaan Limbah (Journal of Waste Management Technology), ISSN 1410-9565 Volume 16 Edisi Suplemen 2013 (Volume 16, Supplement Edition), Pusat Teknologi Limbah Radioaktif (Radioactive Waste Technology Center), (2013)

3. Suprihatin, Kandungan Organik Limbah Cair Industri Batik Jetis Sidoarjo Dan Alternatif Pengolahannya, Pusat Penelitian Lingkungan Hidup Universitas Riau.( 2014)

4. Al-Kdasi, A., Idris, A., Saed, K. and C.T. Guan. Global Nest The Int. J. 6: 222-230. (2004)

5. D. Bashyal, P.L. Homagai, K.N. Ghimire. Journal of Nepal Chemical Society. Vol 26:53-60. (2010)

6. Grezechulska and Morawskin, App. Catal B: Environmental, 36, 45.( 2002)

7. Peraturan Pemerintah No.82/2001, Pengelolaan Kualitas Air Dan Pengendalian Pencemaran Air.

8. Mepmenkes RI Nomer. 492/Menkes/Per/IV/2010 tentang Persyaratan Kualitas Air Minum

9. S. Azumi, M. Bichi. International Journal of Engineering \& Technology, 10(1), pp.101-110.( 2006).

10. P.K Bharti; P Kumar; and V. Singh. Journal of Applied and Natural Sceience, 5(1), pp.132-136.( 2013)

11. Supriyono, Ety susilowati, and Suci Dwi Suryani. Analisa Kadar Logam Timbal dan Seng di Pantai Slamaran Pekalongan secara Spektrofotometer Serapan Atom. Media Farmasi Indonesia Vol 3 No 1.(2008)

12. K. Hasan, and M. Miah. Impacts of Textile Dyeing 
Industries Effluents on Surface Water Quality: A Study on Araihazar Thana in Narayanganj District of Bangladesh. Journal of Environment and Human, (3), pp.8-22.(2014) 